\title{
Feed Intake and Feed Digesbility of Male Merino Sheep with Adding Mahagany Leaves (Swietania mahagoni) as a Source of Tannins in Feed
}

\author{
MK Anam ${ }^{1}, \mathrm{C} \mathrm{Hanim}^{1 *}$ and LM Yusiati ${ }^{1}$ \\ ${ }^{1}$ Department of Animal Feed and Nutrition, Faculty of Animal Science, Gadjah Mada University, Jl. Fauna 3, Bulak \\ Sumur, Sleman, Yogyakarta 52281, Indonesia \\ *Corresponding author. Email: c.hanim@ugm.ac.id
}

\begin{abstract}
The effect of adding Mahogany leaves as a source of tannins in feed on nutrient intake and digestibility in merino sheep was determined in this study. This study used 12 male sheep with an average body weight of 30 to $35 \mathrm{~kg}$. They were confined in individual cages and given feed two times a day. To separate feces and urine samples, there were nylon nets and a urine reservoir under the cages. The feed was given treatments of tannins addition of $0 \%, 1.5 \%$, and $3 \%$. The 14 days adaptation period and 7-days collection period were conducted to obtain samples: forages feed samples, concentrate, forage residue, and stool. These samples tested for their nutrient composition, such as dry matter (DM), organic matter $(\mathrm{OM})$, crude protein $(\mathrm{CP})$, extract ether $(\mathrm{EE})$, crude fiber $(\mathrm{CF})$, and extract without nitrogen (ETN) content. The data obtained were used to determine the value of nutrient intake and digestibility. The result showed that nutrient intake was decreased at added tannins at $1.5 \%$ and $3 \%(\mathrm{P}<0.05)$. In contrast, the addition of $3 \%$ tannins increased nutrient digestibility. It is concluded that Mahogany leaves could be added in merino feed with a level of tannins of $3 \%$.
\end{abstract}

Keywords: Digestibility, Mahogany leaves, nutrient intake, sheep, tannins.

\section{INTRODUCTION}

Merino sheep are one of the famously developed ruminants in Indonesia. However, one of the obstacles that usually occur in raising merino sheep is the fulfillment of nutrients, especially the availability of protein that escapes rumen degradation. Ruminants have a rumen in which the degradation of protein from feed into microbial protein happens then the products are used as the primary source of protein. Still, protein sources that come from microbial protein cannot engage the protein needs of livestock [1]. Thus, adding a higher protein concentrate helps to fulfill protein requirements for livestock [2]. A protein protection agent mostly accompanies the addition of protein concentrate. It aims to protect the proteins from rumen microbes degradation. It is known that tannins are protein protection agents capable of binding proteins. Tannins and proteins will form a tannin-protein complex bond that will escape rumen microbial degradation. The complex bonds are digested in the abomasum and intestines since these bonds will be broken down in an acidic and alkaline environment [3]. As a legume, Mahogany contains tannins in its leaves. The addition of Mahogany leaves in a certain amount can protect the protein in the feed [4].

Based on the explanation above, it is necessary to evaluate nutrient intake, and digestibility from the male Merino sheep feed ratio with Mahogany leaves as a protein protection agent.

\section{MATERIALS AND METHODS}

\subsection{Animals and Feeding Treatment}

The livestock was fed with concentrate and king grass. The drinking water and feed were given ad libitum by giving the ratio of $3 \%$ of the dry matter (DM) requirement per body weight. When the feed and drinking water were fully consumed, they were given extra $10 \%$ addition of the first feed requirement. Mahogany leaves as a source of tannins were dried and ground. The treatment of this research was the addition level of Mahogany leaves by $0 \%, 1.5 \%$, and 3\% based on dry matter of feed. 
Table 1. Feed chemical composition

\begin{tabular}{|l|l|l|l|l|l|l|l|}
\hline Feed ingredient & DM (\%) & OM (\%) & CP (\%) & EE (\%) & CF (\%) & ETN (\%) & Tannins \\
\hline King grass & 17.96 & 86.90 & 6.85 & 0.31 & 32.26 & 48.20 & - \\
\hline Concentrate & 89.32 & 88.33 & 15.18 & 2.62 & 18.06 & 52.48 & - \\
\hline Mahogany leaves & 88.59 & 88.16 & 12.61 & 1.74 & 26.56 & 47.25 & 10.62 \\
\hline
\end{tabular}

\subsection{Collection period}

All livestock were weighed before carrying out the study to determine the initial body weight. The sheep were caged in the individual metabolic pen, while underneath it is given a stool box and a urine reservoir to separate feces and urine. There was an adaptation period of 14 days and then continued with a collection period of 7 days. There were 12 merino sheep used, 10 to 12 months, with an average body weight of 30 to $35 \mathrm{~kg}$. The samples collected during the collection period were forage, concentrate, feed residue, and feces. The remaining feed and feces were weighed and taken $10 \%$ as samples and stored at $5^{\circ} \mathrm{C}$ for 2 days. Each sample was weighed and mixed to get subsamples for chemical analysis.

\subsection{Chemical analysis}

Forage and feed residue was ground on a $1 \mathrm{~mm}$ screen for chemical analysis, while the feces samples were analyzed in fresh condition. Each sample was analyzed with proximate analysis of dry matter (DM), organic matter (BO), crude protein (CP), extract ether (EE), crude fiber $(\mathrm{CF})$ based on the AOAC method [5]. Extract without nitrogen (ETN) was calculated from the results of this analysis. Meanwhile, nutrient intake and digestibility were calculated based on the results of the chemical analysis of feed and feces.

\subsection{Statistical Analysis}

The results of the research data were analyzed using one-way ANOVA. Duncan's New Multiple Range Test (DMRT) was done to show different significance [6].

\section{RESULTS AND DISCUSSION}

This experiment fed Merino sheep, including king grass, concentrate, and tannins from Mahogany leaves. Table 1 presents the chemical composition of each feed ingredient. According to the analysis result, it is known that Mahogany leaves contain $10.62 \%$ of total tannins. Swietenia mahagoni has total tannins of as much as $11.92 \%$ and can bind protein higher than Leucaena leucocephala [7]. The feed consisted of forage and concentrated with the ratio 60:40 (w/w DM basis). The content of CP and TDN in the control feed was $10.18 \%$ and $47.26 \%$. However, increasing the feed CP by $0.04-$

Table 2. Nutrient intake of Merino sheep with different levels of tannins addition

\begin{tabular}{|c|c|c|c|}
\hline \multirow{2}{*}{ Parameters } & \multicolumn{3}{|c|}{ Tannins level (\%) DM basic } \\
\hline & 0 & 1.5 & 3 \\
\hline \multicolumn{4}{|l|}{ In g/day } \\
\hline DM & $986.80 \pm 59.33^{c}$ & $749.65 \pm 30.03^{a}$ & $915.30 \pm 33.30^{b}$ \\
\hline OM & $861.82 \pm 51.40^{c}$ & $650.79 \pm 27.61^{a}$ & $798.02 \pm 31.27^{b}$ \\
\hline $\mathrm{CP}$ & $102.77 \pm 6.73^{b}$ & $85.55 \pm 5.04^{a}$ & $98.78 \pm 3.18^{b}$ \\
\hline $\mathrm{EE}$ & $12.05 \pm 0.83^{b}$ & $9.53 \pm 0.43^{a}$ & $11.58 \pm 0.62^{b}$ \\
\hline CF & $252.43 \pm 14.29 c$ & $180.35 \pm 8.75^{a}$ & $225.36 \pm 13.14^{b}$ \\
\hline ETN & $494.57 \pm 29.71^{c}$ & $375.35 \pm 16.38^{a}$ & $460.95 \pm 12.94^{b}$ \\
\hline \multicolumn{4}{|c|}{$\ln \mathrm{g} /\left(\mathrm{d} \mathrm{kg} B W^{0.75}\right)$} \\
\hline DM & $71.83 \pm 0.57^{c}$ & $56.92 \pm 3.99^{a}$ & $66.14 \pm 3.73^{b}$ \\
\hline $\mathrm{OM}$ & $62.74 \pm 0.47^{c}$ & $49.43 \pm 3.52^{\mathrm{a}}$ & $57.68 \pm 3.30^{b}$ \\
\hline $\mathrm{CP}$ & $7.47 \pm 0.81^{b}$ & $6.50 \pm 0.29^{a}$ & $7.21 \pm 0.27^{b}$ \\
\hline $\mathrm{EE}$ & $0.89 \pm 0.02^{b}$ & $0.73 \pm 0.03^{a}$ & $0.84 \pm 0.06^{b}$ \\
\hline CF & $18.39 \pm 0.13^{c}$ & $13.69 \pm 1.18^{a}$ & $16.33 \pm 1.18^{b}$ \\
\hline ETN & $36.00 \pm 0.23^{c}$ & $28.51 \pm 2.02^{a}$ & $33.29 \pm 1.76^{b}$ \\
\hline
\end{tabular}

a b c Different superscript at the same column shows significantly different $p<0.05$ ) 
Table 3. Nutrient digestibility of Merino sheep with different levels of tannins addition

\begin{tabular}{|c|c|c|c|}
\hline \multirow{2}{*}{ Parameters } & \multicolumn{3}{|c|}{ Tannins level (\%) DM basic } \\
\hline & 0 & 1.5 & 3 \\
\hline \multicolumn{4}{|l|}{ In g/day } \\
\hline DM & $658.96 \pm 46.42^{c}$ & $459.16 \pm 42.19^{a}$ & $594.93 \pm 20.85^{b}$ \\
\hline $\mathrm{OM}$ & $606.28 \pm 40.68^{c}$ & $429.36 \pm 33.9^{a}$ & $549.45 \pm 22.16^{b}$ \\
\hline $\mathrm{CP}$ & $62.76 \pm 4.19^{b}$ & $51.97 \pm 5.23^{a}$ & $62.66 \pm 4.27 \quad b$ \\
\hline $\mathrm{EE}$ & $5.52 \pm 0.48^{b}$ & $4.26 \pm 0.31^{a}$ & $5.67 \pm 0.25 \quad b$ \\
\hline CF & $157.86 \pm 5.02^{b}$ & $107.03 \pm 10.86^{a}$ & $152.11 \pm 20.07^{b}$ \\
\hline ETN & $380.12 \pm 31.52^{b}$ & $266.10 \pm 21.01^{a}$ & $342.98 \pm 5.89 b$ \\
\hline \multicolumn{4}{|c|}{ In g/(d.kg BW $\left.{ }^{0.75}\right)$} \\
\hline $\mathrm{DM}$ & $47.95 \pm 0.95^{c}$ & $34.58 \pm 3.20^{a}$ & $43.06 \pm 2.19^{b}$ \\
\hline $\mathrm{OM}$ & $44.12 \pm 0.78^{c}$ & $32.39 \pm 2.91^{\mathrm{a}}$ & $39.75 \pm 1.99^{b}$ \\
\hline $\mathrm{CP}$ & $4.57 \pm 0.03^{b}$ & $3.93 \pm 0.23^{a}$ & $4.50 \pm 0.14^{b}$ \\
\hline $\mathrm{EE}$ & $0.41 \pm 0.12^{b}$ & $0.33 \pm 0.01^{a}$ & $0.40 \pm 0.02^{b}$ \\
\hline CF & $11.50 \pm 0.28^{c}$ & $8.15 \pm 0.29^{a}$ & $10.01 \pm 0.62^{b}$ \\
\hline ETN & $27.65 \pm 0.65^{c}$ & $19.98 \pm 1.73^{a}$ & $24.82 \pm 0.54^{b}$ \\
\hline \multicolumn{4}{|l|}{$\ln \%$} \\
\hline DM & $66.75 \pm 1.67^{b}$ & $60.45 \pm 1.36^{a}$ & $65.09 \pm 0.93^{b}$ \\
\hline $\mathrm{OM}$ & $70.32 \pm 1.53^{b}$ & $65.27 \pm 1.27^{a}$ & $68.94 \pm 0.61^{b}$ \\
\hline $\mathrm{CP}$ & $61.18 \pm 0.62^{a b}$ & $60.48 \pm 0.56^{a}$ & $62.48 \pm 1.52^{b}$ \\
\hline $\mathrm{EE}$ & $45.71 \pm 1.59 a$ & $44.96 \pm 2.07^{a}$ & $49.78 \pm 0.84^{b}$ \\
\hline CF & $62.52 \pm 1.01^{b}$ & $59.61 \pm 1.59^{a}$ & $60.75 \pm 1.27^{\mathrm{ab}}$ \\
\hline ETN & $76.81 \pm 0.11^{b}$ & $69.60 \pm 3.67^{a}$ & $74.73 \pm 1.64^{b}$ \\
\hline
\end{tabular}

a, b, ab, c Different superscript at the same column shows significantly different $(\mathrm{P}<0.05)$

$0.05 \%$ and TDN by $0.14-0.23 \%$ by adding Mahogany leaves as a tannins source by 1.5 and $3 \%$ only increases the feed CP by $0.04-0.05 \%$ and TDN by $0.14-0.23 \%$.

\subsection{Nutrient intake of Merino sheep}

The results in Table 2 show a significant difference $(\mathrm{P}<0.05)$ in the nutrient consumption of Merino sheep with tannins addition of $0 \%, 1.5 \%$, and $3 \%$ based on DM of feed. All nutrient intake with the addition of Mahogany leaves as tannins source were decreased compared to control feed, yet still, fulfill the livestock requirement for daily maintenance. Nutrient consumption decreased at tannins addition of $1.5 \%$ but increased at 3\%. Dry matter consumption showed an average value of $2.7 \%$ body weight, higher than the necessity of life, namely $2.5 \%-2.7 \%$ for bodyweight 30 $40 \mathrm{~kg}$ [8]. Sheep with a bodyweight of $50 \mathrm{~kg}$ performed $2 \% \mathrm{DM}$ intake from body weight and $\mathrm{CP}$ intake as much as $95 \mathrm{~g} / \mathrm{head} /$ day [9]. Meanwhile, sheep with a bodyweight of $30 \mathrm{up}$ to $40 \mathrm{~kg}$ had $62-77 \mathrm{~g} / \mathrm{head} /$ day of CP intake [8]. Nutrient consumption in this study was not much different from the nutrient consumption of previous studies on male merino sheep fed with peanut straw as sole feed [10]. Animal weight and type of feed can affect nutrient consumption, where the higher the body weight, the greater the nutrient needs to meet their daily needs $[11,12]$. However, the addition of tannins to feed can affect palatability in livestock, thereby reducing feed consumption [13].

\subsection{Nutrient Digestibility}

Table 2 shows nutrient consumption in Merino sheep with a significant result $(\mathrm{P}<0.05)$. Moreover, the nutrient digestibility results (Table 3 ) showed that higher levels of tannins showed a significant increase $(\mathrm{P}<0.05)$ of digestibility values. According to the result, the addition of 3\% Mahogany leaves increased DM, OM, CF, and ETN $10 \%$, also EE $22 \%$ compared to control. Protein digestibility with tannins treatments $1.5 \%$ and $3 \%$ showed higher yields $3 \%$ and $1.5 \%$ compared to control, respectively. High protein digestibility indicates the fast rate of emptying the contents of the rumen. Due to 
tannins that bind protein, the feed escapes and is digested post-rumen [14]. The condensed tannins present in animal feed causes low levels of protein digestibility in the rumen [15]. Increased protein consumption is closely related to the digestibility of feed protein [16]. Tannins and protein bonds are influenced by $\mathrm{pH}$ [17], where the tannins-protein complex will be broken down in lower $\mathrm{pH}$ conditions $(\mathrm{pH}<7)$ in the abomasum [18]. The characteristic of the tannins bond leads to protein protection (by-pass) from rumen microbial degradation, hence increasing the hosts' protein availability.

\section{CONCLUSION}

In conclusion, adding tannins up to $3 \%$ increases the value of nutrient digestibility, allowing for more efficient feed nutrient utilization.

\section{ACKNOWLEDGMENTS}

The authors would like to thank Universitas Gadjah Mada for the grant under the Rekognisi Tugas Akhir (RTA) 2020.

\section{REFERENCES}

[1] C.S. Ali, I.U. Din, M. Sharif, M. Nisa, A. Javaid, N. Hasmi and M. Sarwar.2009 Supplementation of ruminally protected proteins and amino acids: feeds consumption, digestion and performance of cattle and sheep. Int. J. Agric Biol, vol. 11, 2009, pp. 477-482.

[2] H. Hartadi, Feed Composition Table for Indonesia. Gajahmada University Press, 2005.

[3] R.D. Cahyani, LK Nuswantoro., And A. Subrata, Effect of protection of soy flour with mangrove leaf tannins on the concentration of ammonia, undegraded protein and total protein in vitro, Animal Agricultur journal, vol 1,2012. Pp 159166.

[4] T. Robinson, High Plant Organic Content (Translation) Padmawinata, K, ITB, 1995.

[5] AOAC. Official Method of Analysis of the Association of Official Analytical Chemists 18 th ed, Maryland: AOAC International, ed William Harwitz United States of America, 2005.

[6] R.D.G. Steel, and JH Torrie. Principles and Procedures of Statistics $2^{\text {nd }}$ ed New York: McGraw-Hill Book Company, 1980.

[7] L. M.,Yusiati. A. Kurniawati, C. Hanim, and M. A. Anas. Protein binding capacity of different forages tannin. In: IOP Conf. Series: Earth and Environmental Science, vol 119, Semarang 2018,
Pp 1-5. https://doi:10.1088/1755$1315 / 119 / 1 / 012007$

[8] NRC, Nutrient requirements of goats: angora, dairy, and meat goats in temperate and tropical countries Nutrient Requirements of Domestic Animal (Washington DC: National Academy Press, 1981.

[9] P.R. Cheeke, Applied Animal Nutrition Feeds and Feeding. 3rd Ed. Pearson Prentice Hall, 2005.

[10] C. Hanim, and Muhlisin. Nutrient intake and digestibility in Merino sheep fed peanut straw. IOP Conf. Series: Earth and Environmental Science Vol 119 Semarang, 2018.Pp 1-5. https://doi:10.1088/1755-1315/119/1/012005

[11] N. Ngadiyono., E. Baliarti., T.S.M. Widi., H. Maulana and B.A. Atmoko. Effect of breed and initial body weight on daily weight gain of Simmental Ongole Crossbred cattle and Ongole Grad cattle. IOP Conf. Series: Earth and Environmental Science Vol 387, Yogyakarta 2019, Pp 1-4. https://doi:10.1088/1755$1315 / 387 / 1 / 012044$

[12] J.M. Wilkinson, and B.A Stark, Commercial Goat Production. 1 st Ed. BSP Professional Books, 1987.

[13] E. Haslam, Vegetable tannins. In Biochemistry of Plant Phenolics editors: T Swain, JB Harborne and C Van Sumere). The Plenum of London, 1979.

[14] T.J Kempton, J.V. Nolan, and R.A. Leng. 1977. Principle for the use of non-protein nitrogen and by-pass protein in diets of ruminants. World Animal Review, vol 22, 1997 pp.160-181.

[15] J.J. Karchesy, and R.W. Hemingway. 1986; Condensed tannins: $(4 \beta \rightarrow 8 ; 2 \beta \rightarrow \mathrm{O} \rightarrow 7)$-linked procyanidins in Arachis hypogea, LJ Agric. Food Chem. Vol 34, 1986 pp. 966-970.

[16] A.D. Tillman, H. Hartadi, S. Reksohadiprodjo, S. Prawirakusomo and S. Lebdosoekojo, Basic Food Science. Gadjah Mada University Press, 1991.

[17] M. Naczk, D. Oickle, D. Pink and F. Shahidi, Protein precipitating capacity of crude canola tannins: effect of $\mathrm{pH}$, tannin, and protein concentrations. Journal of Agricultural and Food Chemistry, vol 44, 1996 pp. 2144-2148. https://doi.org/10.1021/jf960165k

[18] Diaz-Hernandez, A., M.J. Nixon, F.M. Ball, R.A. Leng, and J.B. Rowe, Protein-tannin complexes are susceptible to proteolytic degradation. Proc. of The New Zealand Society of Animal Production. Vol 57, 1997, 116-119. 